\title{
Temporal variation in body composition and lipid storage of the overwintering, subarctic copepod Neocalanus plumchrus in the Strait of Georgia, British Columbia (Canada)
}

\author{
Melissa Evanson ${ }^{1, *}$, Elizabeth A. Bornhold ${ }^{2}$, Robert H. Goldblatt ${ }^{3}$, Paul J. Harrison ${ }^{3}$, \\ Alan G. Lewis ${ }^{3}$ \\ ${ }^{1}$ Department of Zoology, University of Guelph, Guelph, Ontario N1G 2W1, Canada \\ ${ }^{2}$ Ocean Science and Productivity, Institute of Ocean Sciences, 9860 West Saanich Rd, Sidney, British Columbia V8L 4B2, Canada \\ ${ }^{3}$ Department oi Earth and Ocean Sciences (Oceanography), University of British Columbia, Vancouver, British Columbia \\ V6T 1Z4, Canada
}

\begin{abstract}
Neocalanus plumchrus (Marukawa) was sampled between October 1996 and August 1997 in the upper $400 \mathrm{~m}$ of the water column in Strait of Georgia $\left(49^{\circ} 15^{\prime} \mathrm{N}, 123^{\circ} 45^{\prime} \mathrm{W}\right)$, a large, partly enclosed basin in British Columbia, Canada. The overwintering vertical stage distribution of $N$. plumchrus is described together with the temporal variations in total body length, dry weight, lipid and body composition in copepodite stage $\mathrm{V}(\mathrm{CV})$ and adult females. Adult males and females were found at depths of less than $200 \mathrm{~m}$ from January to March. Regressions of total body length to total dry weight showed significant correlations for $\mathrm{CVs}$ and females. Carbon and nitrogen isotopic analysis $\left(\delta^{15} \mathrm{~N}\right.$ and $\delta^{13} \mathrm{C}$ ) indicated no temporal increase, suggesting a lack of feeding in CVs (October to December) and females (January to March) at depth and a dependency on stored ljpid reserves accumulated during times of high primary production in the euphotic zone. Total lipid content per individual copepod showed significant decreases from 0.5 to $0.2 \mathrm{mg}$ during the time of adult female gonadal development between January and February. A decrease in total dry mass per copepod from 0.9 to $0.4 \mathrm{mg}$ also occurred during this time period. Lipid composition showed preferential retention of long-chained fatty acids until the onset of egg release in March. Significant decreases in carbon and nitrogen from January to February and, to a lesser extent, between February and March were observed, corresponding to periods of gonad maturation and egg release, respectively. Significant increase in nitrogen content suggests the possibility of bacterial ingestion by late moulting $\mathrm{CVs}$. The significant decrease in $\mathrm{C}: \mathrm{N}$ ratio, from 8.7 to 4.1 , suggests a depletion of lipid reserves and resultant reliance on proteins as an energy source for egg release. Variations in organic content verify that the CVs remain in a state of dormancy in which minimal lipid reserves are depleted, while the onset of maturation and reproduction is the major energy consumer.
\end{abstract}

KEY WORDS: Neocalanus plumchrus - Lipid - Body composition - Vertical distribution - Temporal variation

\section{INTRODUCTION}

The calanoid copepod Neocalanus plumchrus (Marukawa) is endemic to the North Pacific and has been observed in relatively high population densities in the northern subarctic (Kawamura \& Hirano 1985). Con-

•E-mail: mevanson@uoguelph.ca sidering these large aggregations, $N$. plumchrus may be expected to play a crucial role in the subarctic food web through predation on microplankton and as potential prey items for planktivores (LeBrasseur et al. 1969, Gardner 1977, Miller et al. 1984, Mackas \& Tsuda 1999). Lipid storage by these marine copepods is of considerable interest due to the inherent role of lipid reserves in seasonal life histories, metabolic transformations of fatty acids in trophic transfers (Sargent \& 
Henderson 1986), and the potential of some lipid classes as measures of recent nutritional history (Håkanson 1984) or reproductive potential (Ohman 1987). Such lipid stores are a major adaptation to extreme seasonality and pulsed production cycles of phytoplankton growth in subpolar regions (Kattner \& Hagen 1995).

The Strait of Georgia is a partly enclosed basin on the west coast of Canada lying between Vancouver Island and the mainland of British Columbia. The Strait comprises an area of $6900 \mathrm{~km}^{2}$, with an average depth of $155 \mathrm{~m}$ and a maximum depth of $420 \mathrm{~m}$. The population of Neocalanus plumchrus in the Strait of Georgia breeds only once a year, with ecdysis, fertilization, and egg laying occurring during the months of November through April and taking place exclusively at mesopelagic depths below $200 \mathrm{~m}$ (Fulton 1973). Egg release commences in early January and extends into midApril, declining over time as the lipid reserves of the adult females are depleted (French 1988). From late February to mid-April, the eggs develop through 6 naupliar (larval) stages and 5 copepodite (juvenile) stages, feeding primarily on phytoplankton at epipelagic depths, at which point they represent the dominant zooplankton in the Strait of Georgia (Harrison et al. 1983). By early June, stage $V$ copepodites (CV), with completed lipid stores, begin their downward migration (Fulton 1973). During their time at depth, it is believed that they conserve energy through a reduction in activity, but CVs retain the ability to feed on alternative food sources such as microzooplankton (Frost et al. 1983, Dagg \& Walser 1987). Adult females have reduced, non-functional mouth parts (Campbell 1934) and do not feed before releasing eggs at depth, suggesting that fecundity is entirely dependent on lipid stores (Fulton 1973). Following the reproductive period, both adults die at depth., with males decreasing in number prior to females, inferring a prompt death subsequent to fertilization (Gardner 1973). Given the central role of $N$ plumchrus in some marine food webs, particularly as a main link between microplankton and higher trophic levels, its large quantities of lipids are of areat importance in the biochemical conversion leading to the production of zooplankton biomass in the Strait of Georgia

The objectives of the present study were to quantify and characterize the lipid composition of Neocalanus plumchrus during its overwintering period and to determine whether potential changes in organic composition were accountable to feeding, moulting, and/or reproductive requirements by overwintering individuals. The Strait of Georgia was selected as a field site due to the implications of $N$. plumchrus as an integral energy source for larval and juvenile fish in the trophic food web.

\section{METHODS}

Collection. Copepods were collected by vertical plankton tows ( 400 to $0 \mathrm{~m}$ and 200 to $0 \mathrm{~m}$ ) at $49^{\circ} 15^{\prime} \mathrm{N}$ $123^{\circ} 45^{\prime} \mathrm{W}$ (Stn DFO1) in the Strait of Georgia. Cruises were made approximately monthly between October 1996 and August 1997 (Cruises M1DFO1 to M11DFO1) using bongo net hauls fitted with a $253 \mu \mathrm{m}$ Nitex net. Upon net retrieval, contents of the codends were transferred to $4 \mathrm{l}$ jars and filled with seawater. When available, replicates were frozen on dry ice upon retrieval and later transferred to a freezer $\left(-20^{\circ} \mathrm{C}\right)$ ashore. Generation 0 refers to samples from October 1996 to March 1997 and Generation I to copepods sampled from April 1997 to August 1997

Identification and sizing. Specimens of CVs, adult females and males were sorted from frozen samples (M1DFO1 to M6DFO1), and subsequently examined and sized using a dissecting microscope and an associated digitizer. Attributes used for stage and species identification included a standard code for limbs, segments, body proportions, and life history cycle stages (Fulton 1972, Gardner \& Szabo 1982, Miller 1988). Dry weight to length regressions were performed to analyse possible correlations for future use as species identification characteristics and to simplify the estimation of biomass

Stage structure. Subsamples of Neocalanus plumchrus from each cruise period were thawed, the first 100 copepods in the subsample were staged, and percentage of each stage as a function of the total was calculated.

$\delta^{13} \mathrm{C}$ and $\delta^{15} \mathrm{~N}$ analysis. For carbon and nitrogen analysis copepods were selected from several cruises, thawed, staged and dried for $>24 \mathrm{~h}$ at $55^{\circ} \mathrm{C}$ prior to analysis. Given the problem of different isotopic compositions in discrete tissue types, whole individuals were analysed. Pooling of samples for each cruise resulted in integrated isotopic values, helping to eliminate variations within individuals (Parsons \& Chen 1995). The amount of heavy isotope in each sample was expressed as the $\delta^{13} \mathrm{C}$ and $\delta^{15} \mathrm{~N}$ value, determined as:

$$
\left[\left(R_{\text {sample }} / R_{\text {standard }}\right)-1\right] \times 1000(\%)
$$

where $R={ }^{13} \mathrm{C} /{ }^{12} \mathrm{C}$ or ${ }^{15} \mathrm{~N} /{ }^{14} \mathrm{~N}$ of the sample and standard. The NBS-21 $=-28.10 \%$ (National Bureau of Standardsj standard for carbon is quoted with respect to Peedee Belemnite (PDB) limestone. The values are given with respert to atmospheric air as well as N-1 and $\mathrm{N}-2$ ammonium sulphate, where $\mathrm{N}-1$ is $+0.43 \%$ and $N-2$ is $+20.32 \%$. Samples were analysed using a PRISM mass spectrometer (VG Isotech). Stable carbon and nitrogen isotopes have been used by a number of authors to examine trophic relationships by using techniques measuring the difference between ${ }^{13} \mathrm{C} /{ }^{12} \mathrm{C}$ and 
${ }^{15} \mathrm{~N} /{ }^{14} \mathrm{~N}$ ratios of organisms as tracers to identify food sources of carbon and nitrogen (Fry 1986, Parsons \& Chen 1995). The isotopic fractionation of tracers generally changes in a predictable way, involving 1 to $2 \%$ $\delta^{13} \mathrm{C}$ and about $3 \% \delta^{15} \mathrm{~N}$ enrichment for each step in a predator/prey relationship (Parsons \& Chen 1995).

Lipid content. The total lipid content of CVs and adults was determined by removal of chloroformmethanol soluble material from intact dry copepod tissues followed by gravimetric measure of the residue and comparison to weights obtained prior to extraction (Miller 1993). For each cruise, 24 to 48 live individuals were identified, staged and placed in pre-weighed aluminum boats. Samples were dried for $>24$ h at $55^{\circ} \mathrm{C}$ for measurement of total dry mass on a microbalance. Lipid extraction from dry tissue was conducted by adding 1 to $2 \mathrm{ml}$ of $2: 1$ chloroform:methanol to each boat containing dried copepods, allowing for extraction in a nitrogen-filled desiccator for $>24 \mathrm{~h}$, and pipetting the solvent out. The lipid-free copepods were then dried for $>24$ h at $55^{\circ} \mathrm{C}$ and re-weighed to obtain 'lipidfree' copepod dry mass. Total lipid was taken as the difference between total dry mass and lipid-free dry copepod mass.

Lipid composition. Values of the fatty acid composition of overwintering Neocalanus plumchrus individuals were compared for temporal variation using gas chromatography. Pooled lots of 2 to 4 intact $C V$ and adult female $N$. plumchrus were extracted by immersion in pre-combusted test tubes $\left(450^{\circ} \mathrm{C}, 4 \mathrm{~h}\right)$ filled with at least $10 \times$ the volume of the copepods (approximately $5 \mathrm{ml}$ ) of $2: 1$ chloroform:methanol and subsequently filled with $\mathrm{N}_{2}$ gas to decrease the incidence of lipid oxidation and degradation. Optima ${ }^{T M}$ brand solvents were used in order to minimize solvent contamination. The test tubes were stored at $4^{\circ} \mathrm{C}$ in a dark environment for $>24 \mathrm{~h}$. Following the extraction period, the copepods were removed from the solvent, now containing the lipids, placed in pre-weighed aluminum boats and dried at $55^{\circ} \mathrm{C}$ to obtain their lipidfree dry weights. The solvent was dried under $\mathrm{N}_{2}$ and the lipid extract left behind was stored at $-20^{\circ} \mathrm{C}$ until further processing. The samples will keep for several months in this state.

The lipid extracts were transmethylated in $0.25 \mathrm{~N}$ $\mathrm{MeOH} / \mathrm{HCl}$ according to Liu (1994) with modifications made by Tony Larson (Department of Earth and Ocean Sciences, University of British Columbia). Fatty acid methyl esters (FAMEs) were analysed using a Hewlett Packard 5890 gas chromatograph equipped with a DB23 column, $50 \%$ cyanopropyl packing, $30 \mathrm{~m} \times 0.25 \mathrm{~mm}$ internal diameter splitter injector and an FID detector. An entire run took 50.2 min and helium was used as the carrier gas. Runs were isothermic at $180^{\circ} \mathrm{C}$ for $34 \mathrm{~min}$, with subsequent oven temperature increases at a rate of 50 to $240^{\circ} \mathrm{C} \mathrm{min}{ }^{-1}$. This temperature was maintained for $15 \mathrm{~min}$ before each run ended. Peaks were only integrated for the first $38 \mathrm{~min}$, i.e. the remaining time was used to burn off impurities. Peaks were identified by cochromatography with identification standards from Sigma ${ }^{\text {TM }}$ and FAMEs derived from cod liver oil.

Peak areas represented relative abundance of each fatty acid as a proportion of the total. Means and standard deviations of percent composition of fatty acids for each cruise were derived. Short- versus longchained fatty acids were averaged for each cruise period.

$\mathrm{C}$ and $\mathrm{N}$ analysis. Analysis of changes in carbon and nitrogen was conducted for $\mathrm{CVs}$ and adult females only. Thawed copepods were sorted and staged under a dissecting microscope, rinsed with $6 \%$ ammonium formate (to wash away potential salt residues) and dried individually in pre-combusted aluminum boats at $55^{\circ} \mathrm{C}$ for $>24 \mathrm{~h}$. Dry mass was established with a microbalance, and total carbon and nitrogen were analysed using a Carlo Erba NCS 1500 analyzer. Rectilinear calibration curves showed $r^{2}=0.99$

Statistical analysis. Regression analysis for sizing was obtained using Microsoft Excel 7.0. Temporal changes in means of isotopic ratios $\left(\delta^{13} \mathrm{C}\right.$ and $\left.\delta^{15} \mathrm{~N}\right)$, lipid mass, total dry mass, \% lipid, and carbon and nitrogen composition were tested for significance using General Linear Models ANOVA Procedure (PROC GLM) and Tukey's Studentized Range (HSD) Test in SAS/STAT 6.12 (SAS Institute Inc. 1990). All tests were run at the $5 \%$ significance level.

\section{RESULTS}

\section{Stage structure and vertical distribution}

At the onset of sampling in 1996, Neocalanus plumchrus stage structure reflected an exclusive CV composition with no maturation into adult male or female individuals (Fig. 1). From the 400 to $0 \mathrm{~m}$ bongo tows, moulting into the adult female with immature gonads was first detected in early December, with large increases taking place between January and February (1997), at which point they dominated the stage structure of the population. Gonadal development in adult females occurred mainly between January and February and the proportion of spent females (few eggs remaining in oviducts, body tissue depleted, no visible ovary) increased thereafter. Adult males were not observed until January, at which point they consisted of $28 \%$ of the total subsample, and were not present in March.

The stage structure of the second generation in early April 1997 included CI to CIV, with CIII being the more 


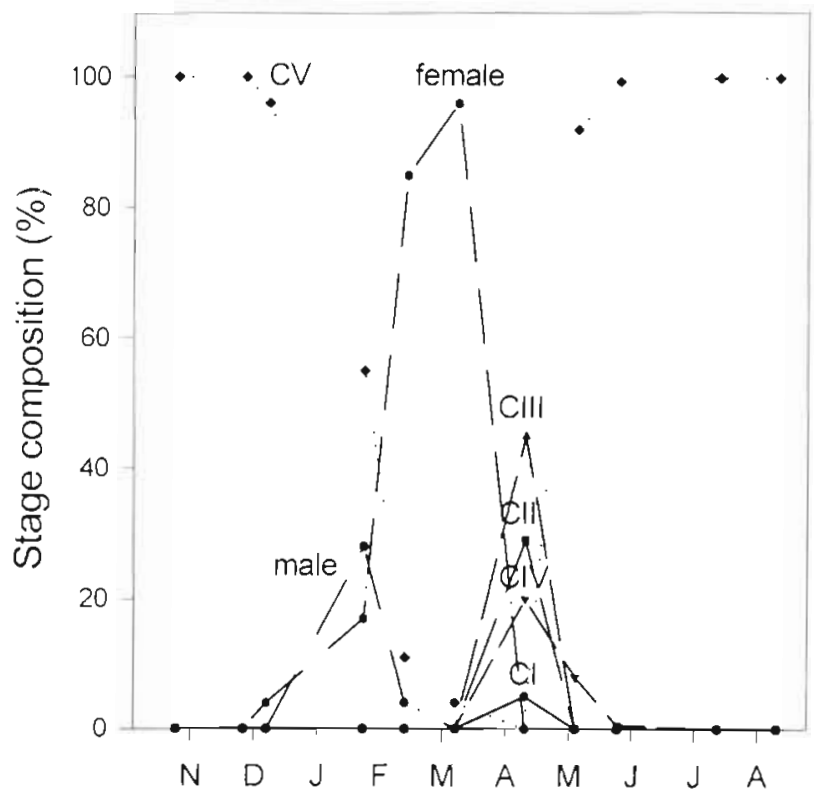

Fig. 1. Neocalanus plumchrus. Temporal variation in development stages ( $\mathrm{Cl}$ to $\mathrm{CV}$, male and female adults) over the upper $400 \mathrm{~m}$ at Stn DFO1 in the Strait of Georgia, 1996-1997 ( $\mathrm{n}=100)$

dominant copepodite stage making up $45 \%$ of the population. CVs first appeared in early May 1997, comprising $92 \%$ of the total, and continued to dominate the stage structure thereafter.

Females (ovigerous and spent) were found in 200 to $0 \mathrm{~m}$ bongo hauls between January and March (1997), ovigerous females were present mainly in early February, spent females being proportionally dominant in March, although first appearing in February. Males (lacking spermatophores) were found in 200 to $0 \mathrm{~m}$ hauls exclusively in January 1997. The presence of early copepodite stages (CI to CIII) was not found in these upper surface water tows (January to March 1997).

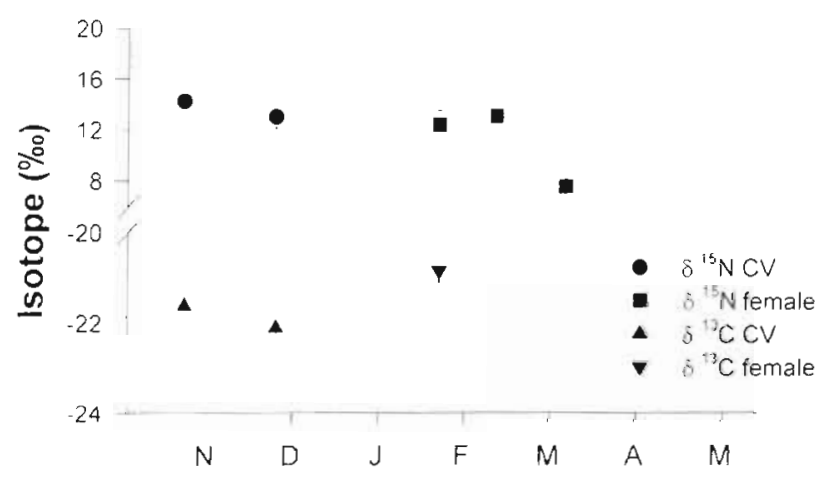

Fig. 2. Neocalanus plumchrus. Temporal variation in $8^{15} \mathrm{~N}$ and $\delta^{13} \mathrm{C}$ in the copepod over the upper $400 \mathrm{~m}$ at Stn DFO1 in the Strait of Georgia, 1996-1997. Vertical lines represent the means $(n=5) \pm 1 \mathrm{SD}$

\section{Sizing}

Regression plots of total length versus total weight were performed for CVs, adult females and males of Generation 0 . CVs and females showed a significant correlation $(\mathrm{p}<0.05)$ with $F_{1,22}=12.254(y=0.00054 x$ $\left.+1.6, \mathrm{I}^{2}=0.37\right)$ and $F_{1,22}=6.332(y=0.00045 x+1.09$, $\left.r^{2}=0.3454\right)$, respectively, where $y$ is the total dry mass and $x$ is the total length. Males did not show a significant correlation $\left(F_{1,22}=3.035, \mathrm{p}>0.05\right)$

\section{$\delta^{13} \mathrm{C}$ and $\delta^{15} \mathrm{~N}$ analysis}

$\delta^{13} \mathrm{C}$ between October and January did not change significantly $\left(F_{26}=2.06, p>0.21\right)$ and ranged from -21.61 to $-20.85 \%$ (Fig. 2 ). The $\delta^{15} \mathrm{~N}$ results showed a significant decrease $\left(F_{4,10}=30.1, p<0.0001\right)$ in females between February and March. No significant variation in $\delta^{15} \mathrm{~N}$ was found during the possible active feeding period from October to November

\section{Lipid content and dry mass}

Total lipid content of Neocalanus plumchrus varied during the 1996-1997 sampling period, with a significant decrease occurring during female gonadal development between January and February $\left(F_{10,416}=58.88\right.$, $\mathrm{p}<0.001$ ) and a significant increase during the lipid accretion period in CV Generation I from May to July $\left(F_{9,328}=17.64, p<0.0001\right)($ Fig. 3A). CV total lipid mass did not fluctuate significantly during the overwintering period. Similarly, significant changes in total dry mass of CVs occurred only from May to August $1997\left(F_{9,328}=\right.$ 16.62, $\mathrm{p}<0.0001$ ) while female dry weight decreased significantly between January and February $\left(F_{10,416}=\right.$ 67.47, p $<0.001$ ) (Fig. 3B)

Significant changes in \% lipid copepod ${ }^{-1}$ dry mass occurred in females between January and March 1997 $\left(F_{10,416}=18.54, \mathrm{p}<0.0001\right)$, as well as in CV Generation I between April and July 1997 (period of lipid accumulation) (Fig. 3C)

\section{Lipid composition}

Constituent FAMEs from the extracted lipid fractions chower nn tempnral variation in percent compocition of short- and long-chained fatty acids between October 1996 and February 1997 (Table 1). Percent composition of long-chained fatty acids remained relatively higher than that of short-chained faity acids until March 1997. The March to August 1997 FAME analysis showed the opposite pattern in relative composi- 

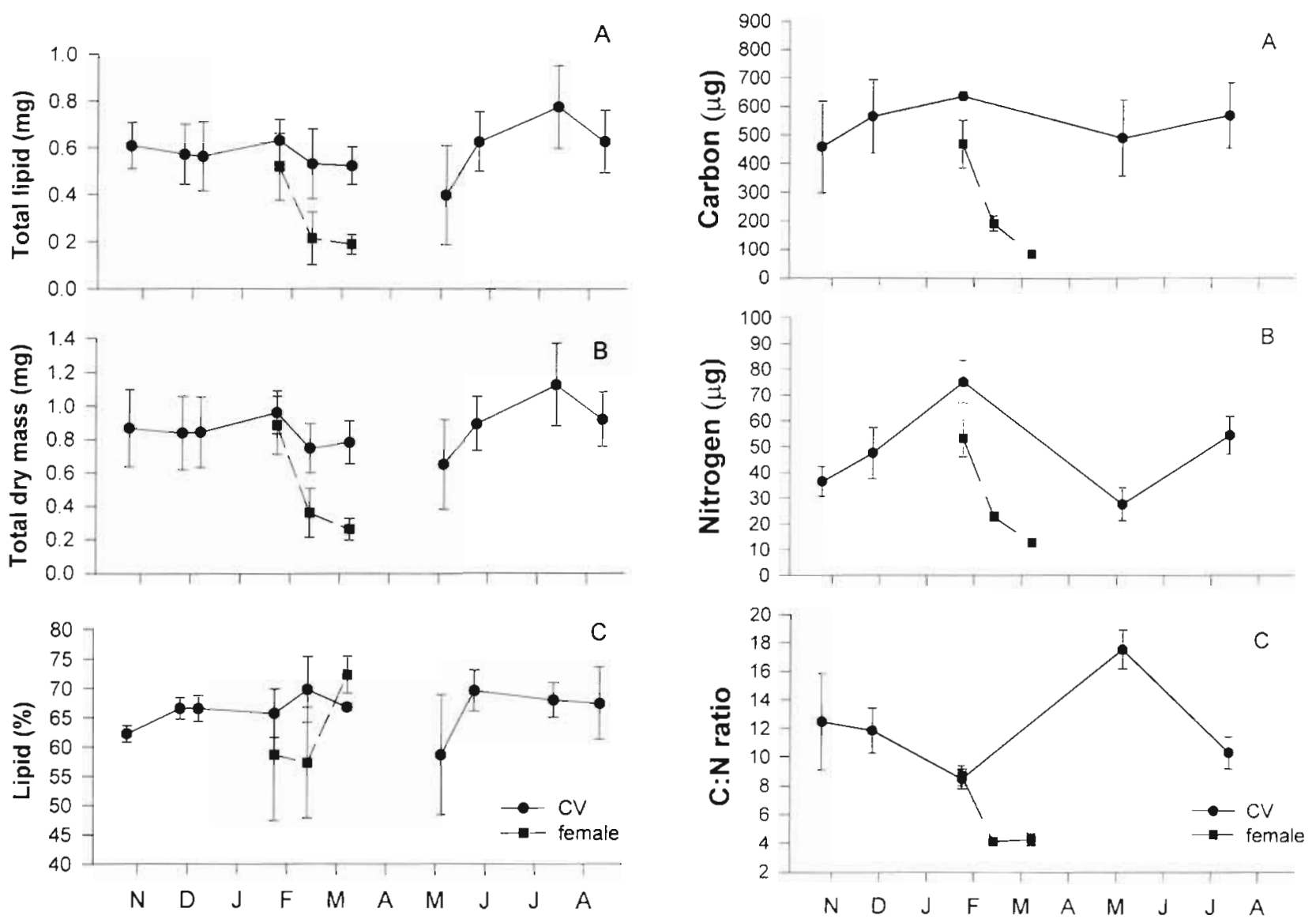

Fig. 3. Neocalanus plumchrus. Temporal variation in (A) lipid mass, (B) total dry mass, and (C) \% lipid per individual over the upper $400 \mathrm{~m}$ at Stn DFO1 in the Strait of Georgia, 19961997. Vertical lines represent the means $(n=24$ to 48$) \pm 1 \mathrm{SD}$

Fig. 4. Neocalanus plumchrus. Temporal variation in (A) carbon content, (B) nitrogen content, and (C) C:N ratio (by atoms) per individual over the upper $400 \mathrm{~m}$ at Stn DFO1 in the Strait of Georgia, 1996-1997. Vertical lines represent the means $(n=5) \pm 1 S D$

Table 1. Neocalanus plumchrus. Temporal variation of \% fatty acid composition of lipids extracted (1996-1997). Values of the means $(\mathrm{n}=5)( \pm 1 \mathrm{SD})$ of percent composition of peak area are given. Carbon chain: number of carbon:number of double bonds and the bracket inserts indicate the number of carbon atoms between the $\mathrm{CH}_{3}$ terminus and the first double bond encountered Trace: percent composition of $<0.05$. Total short- and long-chained are obtained from (n-3) plus non-(n-3) not shown. PUFAs: polyunsaturated fatty acids

\begin{tabular}{|c|c|c|c|c|c|c|c|c|}
\hline $\begin{array}{l}\text { Carbon } \\
\text { chain }\end{array}$ & $\begin{array}{l}\text { Oct } 24 \\
\text { CV }\end{array}$ & $\begin{array}{l}\text { Nov } 15 \\
\mathrm{CV}\end{array}$ & $\begin{array}{c}\text { Generation } 0 \\
\text { Jan } 21 \\
\text { Female }\end{array}$ & $\begin{array}{l}\text { Feb } 10 \\
\text { Female }\end{array}$ & $\begin{array}{c}\text { Mar } 6 \\
\text { Female }\end{array}$ & $\underset{\mathrm{CV}}{\mathrm{May}} 2$ & $\begin{array}{c}\text { Generation } \\
\text { May } 22 \\
\text { CV }\end{array}$ & $\begin{array}{c}\text { Jul } 9 \\
\text { CV }\end{array}$ \\
\hline $18: 4(n-3)$ & $2.1(0.5)$ & $2.3(0.4)$ & $0.3(0.0)$ & $1.5(0.1)$ & Trace & $3.6(0.2)$ & $3.3(0.3)$ & $3.1(0.3)$ \\
\hline $20: 3(n-3)$ & $13.8(1.7)$ & $14.1(1.8)$ & $1.1(0.2)$ & $0.8(0.0)$ & $0.3(0.5)$ & $1.7(0.5)$ & $1.8(0.4)$ & $2.1(0.4)$ \\
\hline $20: 4(n-3)$ & $0.4(0.0)$ & $0.4(0.1)$ & Trace & Trace & $2.3(2.4)$ & $0.2(0.1)$ & $0.3(0.1)$ & $0.1(0.1)$ \\
\hline $20: 5(n-3)$ & $4.5(0.4)$ & $4.5(0.6)$ & Trace & Trace & $3.5(0.3)$ & $12.3(1.0)$ & $10.0(1.3)$ & $7.6(0.4)$ \\
\hline $22: 4(n-3)$ & Trace & Trace & $16.8(0.8)$ & $11.7(4.0)$ & $4.0(2.1)$ & a & d & d \\
\hline $22: 5(n-3)$ & $13.2(7.6)$ & $15.3(1.7)$ & $0.9(0.1)$ & $0.2(0.0)$ & Trace & a & $d$ & a \\
\hline $22: 6(n-3)$ & $5.5(4.2)$ & $3.1(0.2)$ & Trace & $16.2(0.5)$ & $0.5(0.1)$ & $3.8(1.3)$ & $2.5(0.8)$ & $1.4(0.1)$ \\
\hline $\begin{array}{l}\text { Total short-chained } \\
\text { fatty acids }(10: 0-18: 4)\end{array}$ & 46.5 & 47.4 & 47.6 & 43.5 & 57.7 & 57.2 & 57.0 & 64.1 \\
\hline $\begin{array}{l}\text { Long-chained } \\
\text { fatty acids }(20: 0-22: 6)\end{array}$ & 53.5 & 52.6 & 52.4 & 56.5 & 42.3 & 42.8 & 43.0 & 35.9 \\
\hline Sum of known (n-3) PUFAs & 39.5 & 39.7 & 19.1 & 30.4 & 10.6 & 21.6 & 17.9 & 14.3 \\
\hline
\end{tabular}


tion, with short-chained FAMEs showing a significantly higher mean percent composition $\left(F_{1.6}=6.00\right.$, $p<0.0005)$.

FAMEs were particularly rich in a wide range of (n-3) polyunsaturated fatty acids (PUFAs), in particular $18: 4(n-3), 20: 5(n-3), 22: 5(n-3)$ and $22: 6(n-3)$, with a percent composition at times $>40 \%$ in late overwintering CVs. The percent composition of 18:4(n-3) shows a decrease over time, with a notable increase in CVs of Generaion I. Decreases in 22:4(n-3), 22:5(n-3) and 22:6(n3) PUFAs can also be observed over time.

\section{$\mathrm{C}$ and $\mathrm{N}$ content}

CV was the numerically dominant developmental stage from October to January and exhibited significant decreases in carbon $\left(F_{6,14}=5.69, \mathrm{p}<0.004\right.$; Fig. $4 \mathrm{~A})$ and nitrogen $\left(F_{6,14}=11.61, \mathrm{p}<0.0001\right.$; Fig. $\left.4 \mathrm{~B}\right)$ during the moult from CVs into adult females in January. From January to February significant decreases in female copepod carbon and nitrogen content were also detected. During the time of major egg release between February and March, significant yet smaller decreases were observed in carbon and nitrogen content. Carbon and nitrogen values of CVs from May to August 1997 were not significantly different from overwintering CVs. As a consequence of the differential changes in $C$ and $N$ compounds, the $C: N$ ratio of deep females significantly decreased from 8.7 to 4.2 between January and February $\left(F_{6,14}=5.57, \mathrm{p}<0.004\right.$; Fig. $4 \mathrm{C}$ ). The observable increase in $\mathrm{CV}$ nitrogen content that occurred between November and January was significant $\left(F_{4,19}=29.84, \mathrm{p}<0.0001\right)$.

\section{DISCUSSION}

It has been widely accepted that temperate and polar herbivorous copepods utilize their massive lipid reserves for basic metabolic needs to endure long periods of food scarcity (Lee et al. 1971, Lee \& Hirota 1973). Conversely, it has been suggested that the elevated lipid reserves of high latitude species may be primarily explained by their reproductive strategies, which are well adapted to the marked seasonality in subarctic ocean ecosystems (Bamstedt 1986. Hagen \& SchnackSchiel 1996). In the Strait of Georgia, most of the annual primary production occurs in a short burst during the spring and early summer months (Harrison et al. 1983). Thus, it is advantageous for the zooplankton to feed and store energy in preparation for winter months of lower production and food abundance. The observed pattern of lipid accretion and mobilization in Neocalanus plumchrus is consistent with previous works on another copepod (Neocalanus tonsus) with similar energy allocation schemes (herbivory, dormancy, reproduction at depth), which suggest that stored lipids are the immediate energy source for deep overwintering reproduction of non-feeding adults (Jillett 1968, Ohman 1987, Ohman et al. 1989).

Timing of events in the overwintering life cycle of Neocalanus plumchrus in 1996-1997 was similar to that observed by Fulton (1973), with maturation of females and peak abundance of adult males both occurring in the month of January. Analogous comparisons can also be made in the appearance of spent females in January and their abundance increasing thereafter. Results of the vertical distribution of males and females between January and February 1997 are in accordance with Gardner (1973), suggesting either a migration upwards to at least $200 \mathrm{~m}$ following fertilization or the presence of a resident population remaining in shallow waters throughout the year.

Post-reproductive vertical migration has been observed in the Norwegian Sea, where Calanus finmarchicus undergoes reproduction at depth followed by surface spawning in March or April (Ostvedt 1953). Ostvedt (1953) proposed that the onset of such a migration may be initiated by a change in the physiological condition caused by the developing gonad. Conversely, observations of low concentrations of overwintering CV Neocalanus plumchrus at depths $<200 \mathrm{~m}$ have been documented by Gardner (1973) and Mackie (1985) in the Strait of Georgia and Jervis Inlet respectively, indicating the presence of a resident population at shallower depths. Since the occurrence of vertical migration may be an adaptation to ensure that eggs are laid closer to the surface, minimizing their ascent distance, further investigations of adult $N$. plumchrus populations at these depths would be crucial in the analysis of energy allocation as well as potential fitness for the subsequent generation.

In species which do not continually metabolize lipids throughout their temporally dominant stages (e.g. CV), mobilization of lipids can potentially be allocated to 3 distinct phases of growth and morphological change: (1) moult from CV to adult, (2) sexual maturation and gonadal development, and (3) egg release. Similar to Tande's (1982) observations in Calanus finmarchicus, the major period of lipid utilization in Neocalanus plumchrus begins at the onset of sexual maturation. This observed pattern of lipid storage dynamics in $N$. plumchrus is consistent with the suggestion that during the deep-dwelling, overwintering resting stage $(\mathrm{CV})$, metabolic requirements are reduced to a minimum, inferring a state of 'dormancy' (Hagen \& SchnackSchiel 1996). The significant catabolism of storage lipids, therefore, is invested in gonad maturation and egg production (Sargent \& Falk-Petersen 1988). 
Unlike Neocalanus plumchrus, most calanoid copepods require a particulate food supply to complete oogenesis and egg release (Båmstedt \& Tande 1988). In earlier research it was reported that CVs and adult N. plumchrus did not feed at depth (Fulton 1973) although the CVs retain the ability to do so. Based on laboratory and field observations, Fulton (1973) found that CVs fed only in the euphotic zone until mid-July, when they migrated to deeper waters. CVs captured in September did not feed when held in the laboratory and the comparison of their lipid stores and stomach contents to wild individuals captured in January showed no visible difference in stored lipid reserves (Fulton 1973). Campbell (1934) pointed out that the adult $N$. plumchrus has much reduced mouth parts and no masticatory edge to the mandible, suggesting a complete reliance on lipid reserves for reproduction.

From the isotopic results, the suggestion of little or no feeding at depth may be further confirmed by the lack of a significant temporal increase in both $\delta^{13} \mathrm{C}$ and $\delta^{15} \mathrm{~N}$ concentrations. Lipid storage reserves can then be assumed to be the sole predictor of copepod reproductive potential, or total fecundity during the current sampling period. In accordance with this assumption, calanoid lipids generally contain a wide range of fatty acids, compared to fatty alcohols, and in particular can be rich in (n-3) PUFAs, especially 18:4(n-3), 20:5(n-3) and $22: 6(n-3)$, correlating well with the fatty acid composition of phytoplankton lipids (Sargent \& FalkPetersen 1988). Seasonal trends in these phytoplankton markers can therefore be related to the animal's diet or lack thereof, such as in Calanus finmarchicus, where a marked increase in the content of $18: 4(n-3)$ in their lipids from March to June is consistent with a major dietary input of phytoplankton containing 18:4 (n-3) fatty acid. The relative stability of these markers during the 'dormant' $\mathrm{CV}$ stage may indicate a lack of consumption, while ensuing decreases may suggest utilization during times of high energetic requirements corresponding with decreases in total lipid mass. The subsequent lipid accretion period of the following generation may be a clear indication of phytoplankton consumption.

Since Neocalanus plumchrus appears to rely solely on storage reserves acquired prior to its descent into deep waters (for gonad development and subsequent spawning), it is advantageous for it to minimize reserve utilization by entering a state of torpor during its overwintering stage. The lipids accumulated in the spring/ summer months are then utilized during the winter for the final and critical phase of tissue production, the formation of gonads (for N. plumchrus, January to February). Such a strategy of maximal energy allotment into gonad and egg production may significantly increase survival rates of the new generation as well as allow a single female to produce a large quantity of eggs, thereby assisting in the proliferation of the population.

The potential ability of female Neocalanus plumchrus to release eggs in the absence of primary production particulate food implies that maternal proteinor nitrogen-containing phospholipids may be a likely source of additional energy (Ohman 1987). This may be reflected by significant decreases in carbon and nitrogen content during the February to March 1997 sampling interval following the period of significant carbon depletion.

The C:N ratio in Neocalanus plumchrus from the Strait of Georgia showed a trend comparable to that of Calanus finmarchicus over time, where adult females in the spawning period had the lowest measured values as a consequence of lipid depletion (Tande 1982). CVs had generally higher $\mathrm{C}: \mathrm{N}$ values, with insignificant temporal variation. This can be attributed to the period of dormancy from October to December prior to the moult and subsequent adult maturation phases.

Alternatively, the significant increase of nitrogen in CVs between December and February may indicate consumption of nitrogen-rich bacteria by late moulting CVs as an additional food source, potentially for growth or reproduction. Heterotrophic flagellates have been seen to be ingested at high rates by the copepod Diaptomus oregonensis but did not contribute significantly to reproduction while total young of a cladoceran, Daphnia pulicaria, increased in treatments with added bacteria in the presence of algal food (Sanders et al. 1996). This study implies that some foods may be utilized (vs ingested) differently depending on the species. The potential contribution of a late nutritional input to the growth of late CVs into adults would require further investigation as this input would leave the lipids untouched and available solely for reproduction.

\section{CONCLUSION}

Many calanoid copepods have larger lipid stores that are presumably important in reproduction (e.g. Calanus, Pseudocalanus, Microcalanus) but most feed during times of egg production. They maintain the ability to lay eggs during periods of starvation but consumption of additional food helps them produce more eggs or eggs with higher survival rates. A selective primary use of lipids and subsequent metabolism of proteins would suggest a strategy of energy allocation as a consequence of differential requirements through time under starvation conditions. The possibility of energy being allocated to vertical migration following reproduction at depth could have several consequences in terms of the selective retention of energy by the par- 
ental generation at depth prior to their ascent as well as the ensuing fitness of the offspring. The current evidence for discriminate mobilization of lipids and proteins/phospholipids is similar to results with other northern (Calanus helgolandicus) and southern (Neocalanus tonsus) species and illustrates the importance of distinguishing the varying levels of quality storage compounds (lipids) from structural compounds (nitrogen and carbon\}. From the present study it could be postulated that the unusual life history of these dominant subarctic copepods is not only well adapted to the lack of phytoplankton during the winter, but also that internal energy reserves are allotted in a manner that ensures maximum benefit for the subsequent generation

Acknowledgements. We thank Hugh McLean and Drs T. Larson and L. Kunst for field assistance and gas chromatography ald, respectively. Ray Scarsbrook and Dick Beamish are thanked for operation and time on Dept of Fisheries and Oceans ships. Dave L. Mackas (Institute of Ocean Sciences) provided helpful comments on an earlier draft. This work was supported by the Natural Sciences and Engineering Research Council.

\section{LITERATURE CITED}

Båmstedt U (1986) Chemical composition and energy content. In: Corner EDH, O'Hara SCM (eds) The biological chemistry of marine copepods. Clarendon Press, Oxford, p 1-58

Bámstedt U, Tande K (1988) Physiological responses of Calanus finmarchicus and Metridia longa (Copepoda: Calanoida) during the winter-spring transition. Mar Biol 99:31-38

Campbell MH (1934) The life history and post embryonic development of the copepods Calanus tonsus Brady and Euchaeta japonica Marukawa. J Biol Bd Can 1:1-65

Dagg $M J$, Walser WE (1987) Ingestion gut passage, and egestion by the copepod Neocalanus plumchrus in the laboratory and in the subarctic Pacific Ocean. Limnol Oceanogr 32: $178-188$

French SE (1988) Influence of hydrographic properties in Saanich Inlet on ontogenetic migration and retainment of the calanoid copepod Neocalanus plumchrus. MSc thesis, University of British Columbia

Frost BW, Landry MR, Hassett RP (1983) Feeding behaviour of the large calanoid copepods Neocalanus cristatus and N. plumchrus from the subarctic Pacific Ocean. Deep-Sea Res 30(1):1-13

Fry B (1986) Sources of carbon and sulfur nutrition for consumers in three meromictic lakes of New York state. Limnol Oceanogr 31/1):79-88

Fuiton $\mathrm{ju}(1972$, keys and references to ine marine Copepoda of British Columbia. Fish Res Bd Can Tech Rep 313:1-63

Fulton JD (1973) Some aspects of the life history of Calanus plumchrus in the Strait of Georgia. J Fish Res Bd Can 30: $811-815$

Gardner GA (1973) The analysis of zopplankton fluctuations in the Strait of Georgia, with emphasis on the relationship between Calanus plumchrus (Marukawa) and Calanus mar- shallae (Frost). MSc thesis, University of British Columbia

Gardner GA (1977) Analysis of zooplankton population fluctuations in the Strait of Georgia. J Fish Res Bd Can 34(8): $1196-1206$

Gardner GA, Szabo I (1982) British Columbia pelagic marine Copepoda: an identification manual and annotated bibliography. Can Spec Publ Fish Aquat Sci 62

Hagen W, Schnack-Schiel SB (1996) Seasonal lipid dynamics in dominant Antarctic copepods: energy for overwintering or reproduction? Deep-Sea Res 43(2):139-158

Hăkanson JL (1984) The long and short term feeding conditions in field-caught Calanus pacificus, as determined from the lipid content. Limnol Oceanogr 29(4):794-804

Harrison PJ, Fulton JD, Taylor FJR, Parsons TR (1983) Review of the biological oceanography of the Strait of Georgia: pelagic environment. Can J Fish Aquat Sci 40(7):1064-1094

Jillett JB (1968) Calanus tonsus (Copepoda, Calanoida) in southern New Zealand waters with notes on the male. Aust J Mar Freshw Res 19:19-30

Kattner G, Hagen W (1995) Polar hebivorous copepods: different pathways in lipid biosynthesis. ICES J Mar Sci 52(3-4):329-335

Kawamura A, Hirano K (1985) The spatial scale of surface swarms of Calanus plumchrus (Marukawa) observed from consecutive plankton net catches in the North Pacific. Bull Mar Sci 37:626-633

LeBrasseur RJ, Barraclough WE, Kennedy OD, Parsons TR (1969) Production studies inthe Strait of Georgia. Part III Observations on the food of larval and juvenile fish in the Fraser River Plume, February to May, 1967. J Exp Mar Biol Ecol 3:51-61

Lee RF, Hirota J (1973) Wax esters in tropical zooplankton and nekton and the geographical distribution of wax esters in marine copepods. Limnol Oceanogr 18:227-239

Lee RF, Hirota J, Barnett AM (1971) Distribution and importance of wax esters in marine copepods and other zooplankton. Deep-Sea Res 18:1147-1165

Liu K (1994) Preperation of fatty acid methyl esters for gas chromatography analysis of lipids in biological materials. J Am Oil Chem Soc 71:1179-1187

Mackas DL, Tsuda A (1999) Mesozooplankton in the eastern and western Subarctic Pacific: community structure, seasonal life histories and interannual variability. Prog Oceanogr 43:335-363

Mackie GO (1985) Midwater macroplankton of British Columbia studied by submersible Pisces IV. J Plankton Res $7: 753-777$

Miller CB (1988) Neocalanus fleminger, a new species of Calanidae (Copepoda: Calanoida) from the subarctic Pacific Ocean, with a comparative redescription of Neocalanus plumchrus (Marukawa). Prog Oceanogr 20: $223-273$

Miller CB (1993) Development of large copepods durng spring in the Gulf of Alaska. Prog Oceanogr 32:295-317

Miller CB. Frost BW, Batchelder HP. Clemons MJ, Conway RE (1984) Life histories of large, grazing copepods in a subarctic ocean gyre: Neocalanus plumchrus, Neocalanus cristatus, and Eucalanus bungii in the Northeast Pacific. Prog Oceanogr 13:201-243

Unman $\mathrm{NID}$ ( 1 y8 $f)$ Energy sources tor recrutment of the subantarctic copepod Neocalanus tonsus. Limnol Oceanogr 32(6): 1317-1330

Ohman MD, Bradford JM, Jillett JB (1989) Seasonal growth and lipid storage of the circumglobal, subantarctic copepod. Neocalanus tonsus (Brady). Deep-Sea Res 3619): $1309-1326$

Ostvedt DJ (1953) Zooplankton investigations from Weather 
Ship $M$ in the Norwegian Sea, 1948-49. II. The annual vertical migration and its role in the life history of copepods. Hvalradets Skr 40:1-93

Parsons TR, Lee Chen YL (1995) The comparative ecology of a subarctic and tropical estuarine ecosystem as measured with carbon and nitrogen isotopes. Estuar Coast Shelf Sci 41:215-224

Sanders RW, Williamson CE, Stutzman PL, Moeller RE, Goulden CE, Aoka-Goldsmith R (1996) Reproductive success of 'herbivorous' zooplankton fed algal and nonalgal food resources. Limnol Oceanogr 41(6):1295-1305

Editorial responsibility: Otto Kinne (Editor),

Oldendorf/Luhe, Germany
Sargent JR, Falk-Petersen S (1988) The lipid biochemistry of calanoid copepods. Hydrobiologia 167/168:101-114

Sargent JR, Henderson RJ (1986) Lipids. In: Corner EDS, O'Hara SCM (eds) The biological chemistry of marine copepods. Clarendon Press, Oxford, p 59-108

Tande KS (1982) Ecological investigations on the zooplankton community of Balsfjorden, northern Norway: generation cycles, and variations in body weight and body content of carbon and nitrogen related to overwintering and reproduction in the copepod Calanus finmarchicus (Gunnerus). J Exp Mar Biol Ecol 62:129-142

Submitted: December 11, 1998; Accepted: August 2, 1999 Proofs received from author(s): January 24, 2000 